that its members remained good friends until life's end.

Towards the end of 1938, Rymill's first love for Old Penola Station claimed him, and he returned to Australia for good, despite his tentative plans for a further Antarctic expedition and despite pleas from Sir Douglas Mawson, both before and after the war, to consider establishing a base in the Australian Antarctic Territory. In the words of Riley, he became a 'station master.' His plans for the station were soon interrupted by the outbreak of war, although he was at first rejected for service because of an old knee injury. In 1942 he was commissioned as a lieutenant, RANVR, and given a humdrum job in naval operations, his leadership qualities and polar expertise unused. In 1944 he gained his release from the navy on the grounds that he would be better employed raising sheep and cattle to feed the troops. He was now able to devote his life to revitalizing the Old Penola Station into an efficient and thoroughly modern concern, drawing in his methodical way on all that agricultural science could offer. As a renowned horseman himself, he also set up a riding centre. He died in 1968, aged 63, as a result of a car accident on the road to Adelaide, while following an ambulance taking his wife to hospital for treatment. Rymill held the Polar Medal with Arctic and Antarctic clasps and the Founder's Medal of the RGS, and he is, as the author fails to mention, commemorated in three place-names in the British Antarctic Territory and one in the Australian Antarctic Territory.

A foreword to this book contains a moving tribute to Rymill by Colin Bertram, one of three surviving members of the BGLE. Another tribute by Stephenson (last of those who served on both the BAARE and the BGLE) is referred to in the text as included in the final chapter, but has in fact been omitted. This omission and an unevenness in some passages suggest that the text has been cut down from a longer manuscript. Better editing was needed, as indicated also by a rather large number of misprints. However, these shortcomings hardly detract from the author's splendid portrait of a great man, a great Australian, and a polar specialist of the days when it was still possible to 'explore.' (Geoffrey Hattersley-Smith, The Crossways, Cranbrook, Kent TN17 2AG.)

ALASKA AT WAR, 1941-1945: THE FORGOTTEN
FRONT REMEMBERED. Fern Chandonnet (Editor). 1995. Anchorage: Alaska at War Committee. xviii +455 p, illustrated, hard cover. ISBN 0-9646980-0-5. \$US39.95.

The Second World War and the Cold War that followed it constitute the main turning point in the history of Alaska. Before 1941, the state, or territory as it was then, was a half-forgotten northern backwater with a population of about 70,000 , ignored by the rest of the country, its economy based on the extraction of natural resources. It was the war, and more particularly the immense expenditures on defence that came with it and the subsequent Cold War, that pushed Alaska to the forefront of the American defence effort, and that changed the landscape of the region forever. In the 15 years after the attack on Pearl
Harbor, tens of thousands of military personnel came to Alaska, building first the Alaska Highway, and then huge military installations in Anchorage, Fairbanks, and other locations. With the onset of the Cold War, Alaska found itself on the front line of Russian-American tensions, and further military spending, including particularly the construction of the DEW (distant early warning) line in the 1950 s, totally changed the economy of the state. The great oil boom of the 1970s changed it again, but it was the war that first pushed the state into the modern age.

This volume contains a collection of papers presented at a conference held in November 1993 in Anchorage to remember the war and its effect on the state and on the neighbouring Yukon Territory, which was equally transformed by the construction of the highway. The event was held also to mark the fiftieth anniversary of the opening of the Alaska Highway, perhaps the best known physical manifestation of the war in the extreme northwestern part of the continent. The choice of topics and speakers represented in ths volume shows how much Alaska and the study of its history have changed in recent decades. Had this conference been held in 1953, on the highway's tenth anniversary, it likely would have had an exclusively military emphasis. It is a reflection of the increasing diversity of interest in the state's history that the 1993 session included 'Minorities in Alaska's military,' 'Aleut relocation and restitution,' and 'War's impact on the home front,' as well as more traditional topics such as 'War in the North Pacific' and 'Defending the territory.' It is also a sign of the times that one paper included in this book is by an American of Japanese ancestry, who was interned during the war, another is by a Japanese professor of military and diplomatic history, while another is by a Russian from Irkutsk.

It is always difficult to summarize a book that consists of a collection of papers, and it is made even more difficult in this case by the fact that this book has 67 chapters, each a separate paper, as well as an introduction and a select bibliography. Some of the contributors are professional historians, others are military men or journalists, and a good number are simply citizens who witnessed or are interested in a vital period in the history of their state. With this number of contributors, and this variety of expertise and background, the chapters are bound to be somewhat uneven in tone and quality, but this only adds to the sense that the book represents a very wide spectrum of experience, rather than being a production solely of academics. There is no point in choosing winners and losers among the contributors to this book; the academics write like academics - carefully and precisely, with careful annotations while the non-academics write in a looser style. But virtually everything in the book is valuable to a student of the subject.

For a collection of conference papers, Alaska at war is an uncommonly handsome book, doubtless the result of the fact that its production was subsidized by the Alaska Humanities Forum, the National Endowment for the Hu- 
manities, the Quest for Truth Foundation, and the US Department of Defense Legacy Program. The book has been published in a large format, with a generous assortment of maps and photographs, and a particularly attractive reproduction of war art on the dust cover.

The only real criticism that can be levelled at this book is that, like any collection of specialized papers, it is not a very good or accessible introduction to the subject of Alaska and World War II, since it presupposes a fair amount of knowledge of the subject covered. But it is evidently not intended to serve this purpose; instead, it provides for the specialist the current state of scholarship on the subject. It will stand as a valuable source of scholarship, explanation, and personal recollection of events concerning the war, but the general reader wanting an overview of the subject should first consult one of the general histories of the state, such as Naske and Slotnik's Alaska: a history of the 49th state. Given some previous knowledge of the subject, this book is a treasure house of information. (William R. Morrison, University of Northern British Columbia, Prince George, British Columbia, Canada.)

\section{STRUCTURE, FUNCTION AND EVOLUTION OF} TEETH. Patricia Smith and Eitan Tchernov (Editors). 1992. London and Tel Aviv: Freund Publishing House. $570 \mathrm{p}$, illustrated, soft cover. ISBN 965-222-270-4.

Smith and Tchernov's edited volume is based upon papers presented at the 8th International Symposium on Dental Morphology. The Symposium provided a forum for palaeontologists, embryologists, dental anthropologists, anatomists, and geneticists to exchange information on the microstructure, embryology, morphology, function, and evolution of teeth. Of particular relevance to researchers interested in the biology of the north are two chapters in the third section dealing with human populations.

The first is by J.T. Mayhall and L. Alvesalo, and deals with sexual dimorphism in the maxillary first molars in the residents of the island of Hailuoto in Finland. Although the dental health and genetics of this population have been extensively investigated since the 1970 s, little research has been conducted on its dental morphometrics. Mayhall's and Alvesalo's results suggest that while the Hailuoto islanders' cusp heights are similar to those reported in Japanese and Canadian Inuit populations, the overall relationship is stronger to mainland Finnish patterns and other Caucasians.

The second paper of relevance to northern anthropology is by G.R. Scott and V. Alexandersen, and explores dental morphological variation among medieval Greenlanders, Icelanders, and Norwegians. The authors' aim was to assess evidence for possible gene flow from the Inuit into the Norse Greenlandic population between the tenth and sixteenth centuries. Their findings are that in the Greenlandic Norse skeletons there is temporal stability in oral health parameters (such as caries, antemortem tooth loss, and periapical osteitis), along with decreases in overall body size and increasing third molar agenesis. These are traits associated with contemporary populations in Iceland and Norway, and suggest an overall congruence with European dental patterns. However, the study also indicated that the Greenlandic Norse showed significant changes in the frequency and expression of oral tori, characters more commonly associated with Inuit populations. It was concluded that there was no incontrovertible evidence for gene flow between Norse and Inuit communities, and the authors speculate that the unusual tori patterns were the result of a combination of founder effect and genetic drift.

While most of Structure, function and evolution of teeth is not of direct relevance to anthropologists specialising in northern populations, it is an excellent compilation of some of the most recent and exciting research in the field, and will prove to be a valuable reference source for years to come. (Elizabeth Cruwys, Scott Polar Research Institute, University of Cambridge, Lensfield Road, Cambridge $\mathrm{CB} 2$ 1ER.)

THE FALKLANDS AND THE DWARF: THE CRUISE OF HMS DWARF IN THE FALKLAND ISLANDS 1881-1882. C.H. Layman and J. Cameron. 1995. Chippenham: Picton Publishing. xiv +160 p, illustrated, hard cover. ISBN 0-0948251-76-X. £25.00.

During the late nineteenth century, the Royal Navy undertook a bewildering variety of duties quite apart from participating in the various wars that took place during the period. One of the most important of these was the gathering of intelligence concerning potential enemies, which, as this was the period of 'splendid isolation,' meant, in effect, all of those countries that were not coloured red on the map. Other tasks included hydrographic surveying, the exploration of remoter parts of the globe, and action in aid of the civil power and general policing duties in those British dependencies where such was required and where there was no adequate local machinery for so doing. These latter were often combined with cruises, the ostensible purpose of which was to provide training and to keep ships' crews up to scratch, together with the general showing of the flag.

This entertaining little volume presents a first-hand account of one such voyage, that of HMS Dwarf in the Falkland Islands in 1881-1882. The reason for the visit of the ship to the islands was the enforcement of legislation establishing a close season for sealing. As the government had no effective means for doing this, it requested help from the senior officer of the South East American station, based at Montevideo, who arranged for Dwarf, a small vessel of four guns with a crew of 85 , to undertake the duty. But for a fortunate circumstance, the records of Dwarf $\mathrm{s}$ cruise would have remained as formal reports to the Admiralty, which would now be buried in the naval archives. However, in command of Dwarf was a remarkable officer, Commander Sir William Wiseman, Bt, who wrote a series of detailed letters on the doings of the ship to his wife, and these letters are presented in the book. 